\title{
Funkcionalizált aliciklusok diverzitás orientált szintézise dipoláros cikloaddíciót követő metatézis reakciókkal ${ }^{\dagger}$
}

\author{
BENKE Zsanett Amália, REMETE Attila Márió és KISS Loránd*
}

Szegedi Tudományegyetem, Gyógyszertudományi Kar, Gyógyszerkémiai Intézet, Eötvös utca 6., 6720 Szeged, Magyarország

\section{Bevezetés}

Az elmúlt két évtizedben a diverzitás orientált szintézisek (DOS) alkalmazása széles körben elterjedt háromdimenziós kismolekulákból álló molekulakönyvtárak létrehozására. A múlt évtized óta a szerkezetileg és funkcionálisan változatos molekulák előállítására nagyobb figyelem irányul szemben a molekulaméret növeléssel ${ }^{1-3}$.

A funkcionalizált izoxazolinvázat tartalmazó vegyületek változatos biológiai tulajdonságokkal rendelkeznek (antivirális, antibakteriális, gombaellenes hatás), így fontos szerepet játszanak a gyógyszerkémiában ${ }^{4,5}$. (1. ábra) Továbbá hasznos intermedierek lehetnek különféle kémiai átalakításokban, a felhasználásukkal például amino-alkoholok, amino-diolok, $\beta$-hidroxi-ketonok állíthatók elö ${ }^{6-8}$.
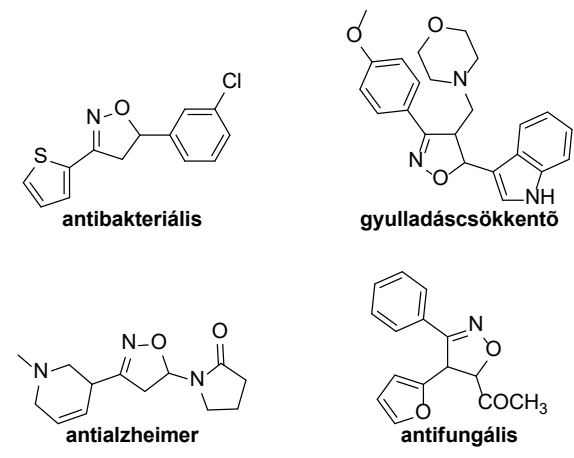

1. ábra. Néhány biológiailag aktív izoxazolin-származék

Nitril-oxidok 1,3-dipoláros cikloaddíciója széles körben alkalmazott eljárás izoxazolinok szintézisére. Mivel a nitril-oxidok nem stabil dipólok, ezért in situ generálják ezeket a reakcióelegyben. Ehhez a két legismertebb módszer: a Huisgen-módszer, amikor aldoximból kiindulva; valamint a Mukaiyama-módszer, amikor primer nitroalkánból kiindulva állítják elő a nitril-oxidot ${ }^{9-11}$. (2. ábra)

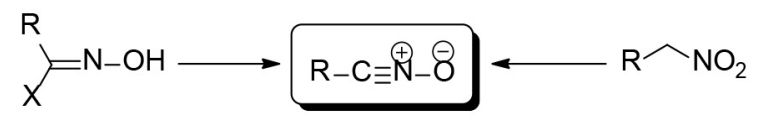

2. ábra. Nitril-oxid generálása
A metatézis reakció egy hatékony eljárás $\mathrm{C}=\mathrm{C}$ kötések létrehozására. Köszönhetően az enyhe reakciókörülményeknek és a szerkezetileg változatos molekulák létrehozására való készségének a metatézis egy széles körben elterjedt eljárás. A ruténium-alapú katalizátorok megjelenésével az olefin-metatézis szélesebb teret hódított magának. Ezek kitűnő funkciós csoport toleranciával rendelkező katalizátorok, továbbá jelentősen stabilak az oxigénnel és a nedvességgel szemben. A 20. század végén az olefin metatézisben áttörést jelentett Yves Chauvin mechanizmus-javaslata ${ }^{12-16}$. (3. ábra)

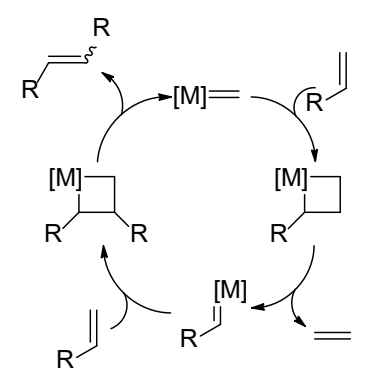

3. ábra. Chauvin-metatézis mechanizmus

Kutatócsoportunkban korábban már állítottak elő izoxazolin-származékokat nitril-oxidok 1,3-dipoláros cikloaddíciójával telítetlen $\beta$-aminosavakból kiindulva. Továbbá ciklusos $\beta$-aminosavak, valamint $\beta$-laktámok továbbalakítását végezték el olefin metatézis reakciók (ROM és $\mathrm{CM}$ ) alkalmazásával. Így változatosan szubsztituált $\beta$-aminosavakat, valamint $\beta$-laktámokat állítottak elő sikeresen ${ }^{11,17}$.

\section{Eredmények}

\subsection{Izoxazolin-származékok szintézise}

Aliciklusos gyürüvel kondenzált izoxazolin-származékok $[( \pm)-7 \mathbf{a b}-( \pm)-27 \mathbf{a b}]$ regio- és sztereoizomerjeit nitril-oxidok $\left(\mathrm{EtNO}_{2}, \quad n \mathrm{PrNO}_{2}\right.$, valamint $\mathrm{BnNO}_{2}$-böl kiindulva, dehidratáló ágensként $\mathrm{Boc}_{2} \mathrm{O}$-et, bázisként DMAP-t alkalmazva) 1,3-dipoláros cikloaddíciójával állítottuk elő különböző ciklodiének (ciklopentadién, 1,4-ciklohexadién, 1,3-ciklohexadién, 1,5-ciklooktadién, 1,3-ciklooktadién, illetve 2,5-norbornadién) kiindulási anyagként történő felhasználásával. ${ }^{18}$

\footnotetext{
† Benke Zsanett Amália azonos címú PhD értekezéséhez kapcsolódó összefoglaló tézisfüzet alapján készült

* Tel.: +36 30-8535341; e-mail: kiss.lorand@szte.hu
} 
Amennyiben ciklopentadiént (1) alkalmaztunk kiindulási anyagként, a cikloaddukt $( \pm)-\mathbf{1 0}-( \pm)-12$ (minden esetben az a regioizomer képzödött, amelyikben az izoxazolingyürü O-atomja közelebb helyezkedik el a ciklopenténgyürü $\mathrm{sp}^{3}$ C-atomjához) mellett fötermékként a diciklopentadiénnel kondenzált izoxazolin regioizomereket $( \pm)-7 \mathbf{a b}-( \pm)-$ 9ab kaptuk meg. 1,4-Ciklohexadiénböl (2) kiindulva csak nyomokban jutottunk cikloaddíciós termékhez, azonban ennek helyzeti izomerjéből, az 1,3-ciklohexadiénből (3) kiindulva regioizomer termékeket kaptunk. A fötermékek minden esetben a $( \pm)-16 a-( \pm)-18 a$ vegyületek voltak. Amennyiben fenil-nitrometánt alkalmaztunk nitril-oxid forrásként, az izomer cikloaddíciós termék ( $( \pm)-18 b$ (amely- ben az izoxazolingyürü O-atomja közelebb helyezkedik el a ciklohexéngyürü $\mathrm{sp}^{2} \mathrm{C}$-atomjához) képződése elmaradt. 1,5-Ciklooktadién (4) reakcióiban egyetlen terméket [( \pm )19-( \pm -21] kaptunk minden esetben közepes hozammal. 1,3-Ciklooktadién (5) esetében szintén regioizomerek keverékét $[( \pm)-22 a b-( \pm)-24 a b]$ kaptuk. Konstitúciós szerkezetüket minden esetben sikeresen meghatároztuk 2D NMR spektrumok (COSY, HSQC) alapján. 2,5-Norbornadiénre (6) végzett nitril-oxid cikloaddíciós reakcióban két terméket kaptunk jó hozammal minden esetben. A főtermék az exo sztereoizomer volt, a melléktermék az endo sztereoizomer $^{19}$. (4. ábra)

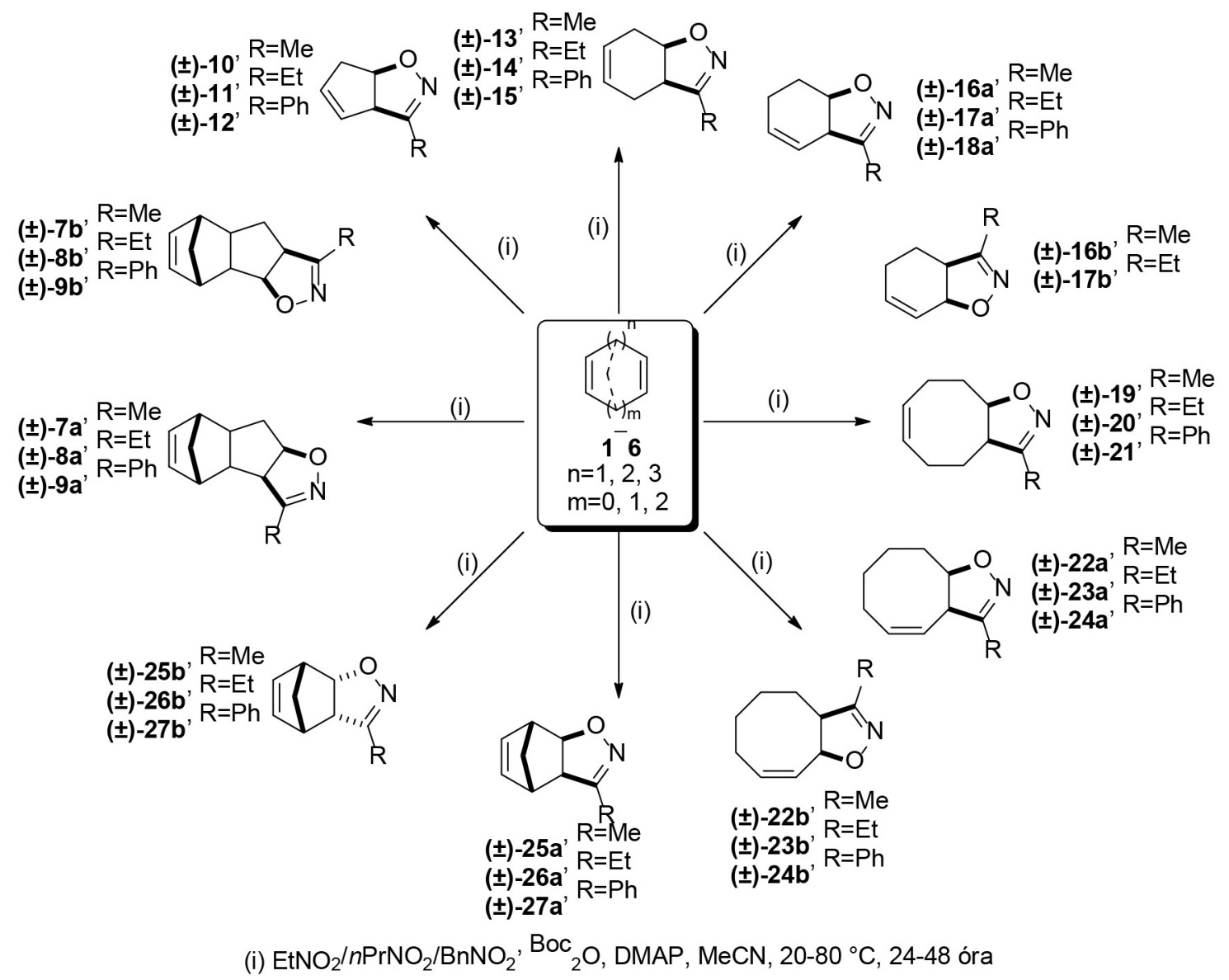

4. ábra: Aliciklusos gyűrüvel kondenzált izoxazolin-származékok szintézisei

Az így előállított izoxazolin-származékokat $[( \pm)-7 \mathbf{a} / \mathbf{b}-( \pm)-$ 27a/b] kiindulási anyagként használtuk a továbbiakban.

\subsection{Izoxazolin-származékok gyürünyitó metatézissel történő átalakításai}

Az izoxazolin-származékok sztereokontrollált gyürünyitó metatézisét elvégezve jó, illetve kiváló hozamokkal jutottunk a gyürünyitott termékekhez. A gyürünyitó metatézist (ROM) etilén atmoszférában végeztük, szobahőmérsék- leten, ruténium-alapú katalizátor (1. generációs Grubbs, G1, illetve Hoveyda-Grubbs HG1, 2. generációs Grubbs G2, illetve Hoveyda-Grubbs, HG2, valamint 3. generációs Grubbs, G3 katalizátor) jelenlétében. (5. ábra $)^{20-24}$

A gyürünyitott termékek mellett kisebb mennyiségü polimer termékek képződését is tapasztaltuk. A polimerek viszszaszorítására jó megoldásnak bizonyult a reakció lejátszódását követően a katalizátor elroncsolása, ezt $\mathrm{NaHCO}_{3} / \mathrm{H}_{2} \mathrm{O}$ és $\mathrm{MeOH}$ eleggyel végeztük $\mathrm{k}^{25-27}$. 


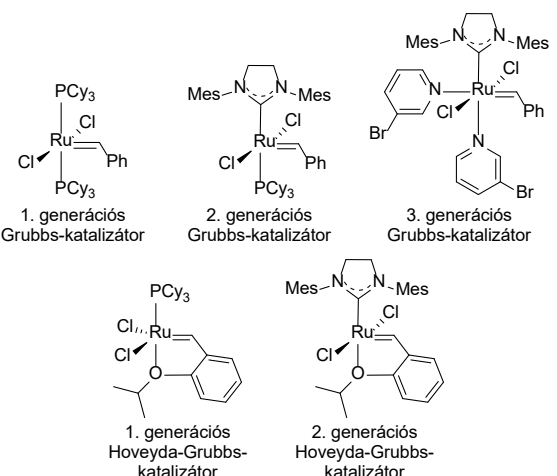

5. ábra. Alkalmazott Ru-alapú katalizátorok

Azáltalunk előállított ciklookténvázzal kondenzált izoxazolin-származékok közül a 3-metil-ciklooktén-izoxazolin [( \pm -19] gyürünyitó metatézisét végeztük el. A HG1 katalizátor alkalmazásával jobb hozamot értünk el, mint a G1 katalizátor alkalmazásával. A reakció során egyetlen terméket izoláltunk oszlopkromatográfiás tisztítást követően 68\%-os hozammal. (6. ábra)

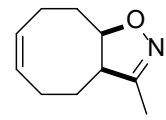

$( \pm)-19$

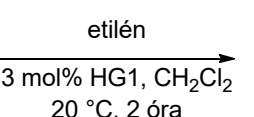
$20{ }^{\circ} \mathrm{C}, 2$ óra
6. ábra: 3-Metil-ciklooktén-izoxazolin [(土)-19] gyưrűnyitó metatézise

A norbornénvázzal kondenzált izoxazolin-származékok [( \pm$)-25 a-( \pm)-27 \mathbf{a}]$ gyürünyitó metatézise során célunk volt a kereskedelmi forgalomban kapható katalizátorok teljesítőképességének vizsgálata. A reakciók során szelektíven, egyetlen terméket izoláltunk, a $( \pm)-29-( \pm)-31$ gyürünyitott izoxazolin-származékokat. (7. ábra)

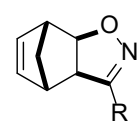

$( \pm)-25 a, R=M e$
$( \pm)-26 a, R=E t$
Re

(土)-27a'

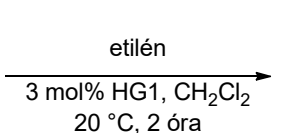

$20{ }^{\circ} \mathrm{C}, 2$ óra

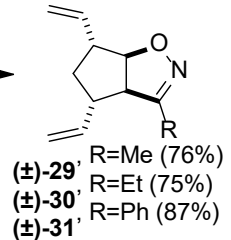

7. ábra. Divinil-szubsztituált ciklopentánvázzal kondenzál izoxazolinszármazékok szintézisei
Azt tapasztaltuk, hogy a HG1 katalizátor jó, illetve kiváló hozammal eredményezte a gyürűnyitott termékeket. A 2. generációs katalizátorok (G2 és HG2) esetében az 1 órás reakcióidővel jobb eredményt értünk el, mint 2 órás reakcióidővel, valamint a 3. generációs Grubbs-katalizátor különösen rövid reakcióidőt igényelt. Ennek legfőbb oka polimerek képződése volt. (1. Táblázat)

\begin{tabular}{cccccc}
\hline Vegyületszám & G1 & G2 & HG1 & HG2 & G3 \\
\hline $\mathbf{(} \pm)-\mathbf{2 9}$ & $33 \%$ & $22 \%$ & $76 \%$ & $13 \%$ & $30 \%$ \\
$( \pm)-30$ & $58 \%$ & $15 \%$ & $75 \%$ & $34 \%$ & $49 \%$ \\
$( \pm)-31$ & $93 \%$ & $10 \%$ & $87 \%$ & $25 \%$ & $44 \%$ \\
\hline
\end{tabular}

1. Táblázat. Izolált hozamok $[( \pm)-29-( \pm)-31]$

\subsection{Izoxazolin-származékok keresztmetatézissel történő átalakítása}

\subsubsection{Keresztmetatézis metil-akriláttal, illetve metil-vinil-ketonnal}

A gyürünyitó-metatézissel előállított dialkenil-szubsztituált izoxazolin-származékok $[( \pm)-28-( \pm)-31] \mathrm{C}=\mathrm{C}$ kötése további funkcionalizálásokra ad lehetőséget. A keresztmetatézis $\mathrm{CH}_{2} \mathrm{Cl}_{2}$ közegben, Ru-alapú katalizátorok $(\mathrm{G} 2, \mathrm{HG} 2$ és G3) jelenlétében történt. Kapcsoló partnerként metil-akrilátot és metil-vinil-ketont alkalmaztunk. A keresztmetatézis reakciók sztereokontrollált módon játszódtak le és minden esetben a termék $E$ geometriával rendelkezett.

A ( \pm )-28-as vegyület átalakítása során kapcsoló partnerként metil-akrilátot alkalmazva a kétszeresen kapcsolt vegyület $[( \pm)-32 c]$ mellett egyszeresen kapcsolt regioizomerek $[( \pm)-$ 32a és ( \pm -32b] is képződtek változó arányban és hozammal. Azt tapasztaltuk, hogy szobahőmérsékleten, 6 órás reakcióidővel, HG2 katalizátor jelenlétében elvégezve a reakciót jelentősebb mennyiségü egyszeresen kapcsolt termékek [( \pm -32a és $( \pm)-32 b]$ képződtek. Reflux hőmérsékleten elvégezve a reakciót, 2 órás reakcióidővel, szintén HG2 katalizátor jelenlétében jó hozammal jutottunk a kétszeresen kapcsolt termékhez $[( \pm)-32 c]$. (8. ábra)

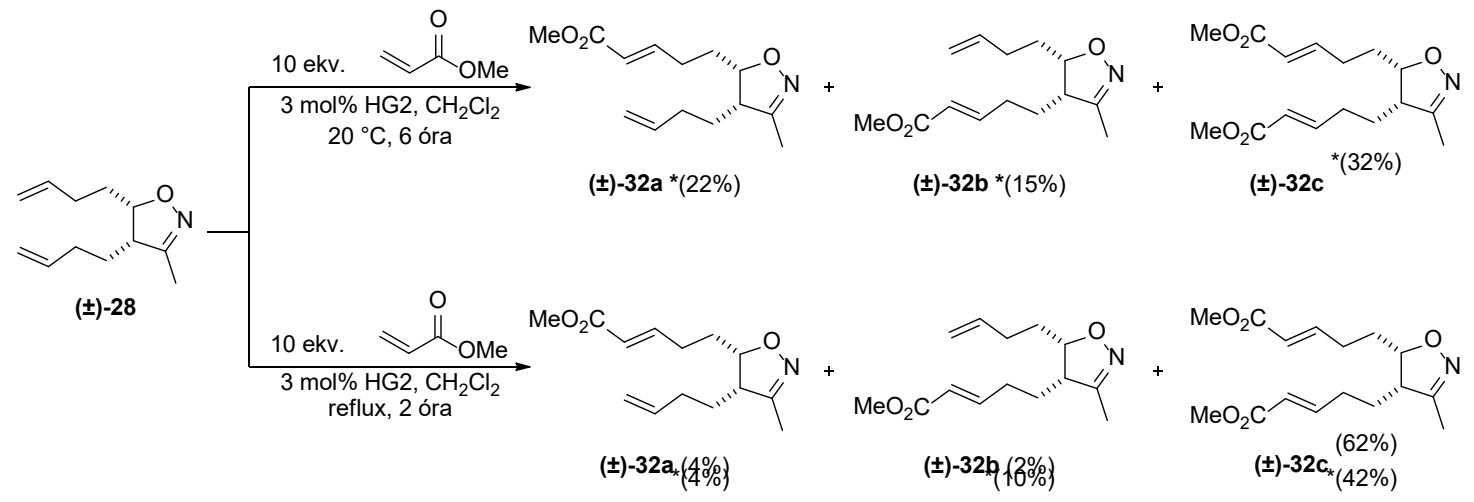

8. ábra. Keresztkapcsolt termékek szintézise metil-akriláttal; (*katalizátor elroncsolással kapott hozamok) 
Abban az esetben, ha kapcsoló partnerként metil-vinil-ketont alkalmaztunk, az előzőekhez hasonló módon egyszeresen kapcsolt regioizomereket $[( \pm)$-33a és $( \pm)-33 b]$ és kétszeresen kapcsolt terméket $[( \pm)-33 c]$ kaptunk. A reakciót HG2 katalizátor jelenlétében szobahőmérsékleten 6 órás reakcióidővel végeztük el. (9. ábra)

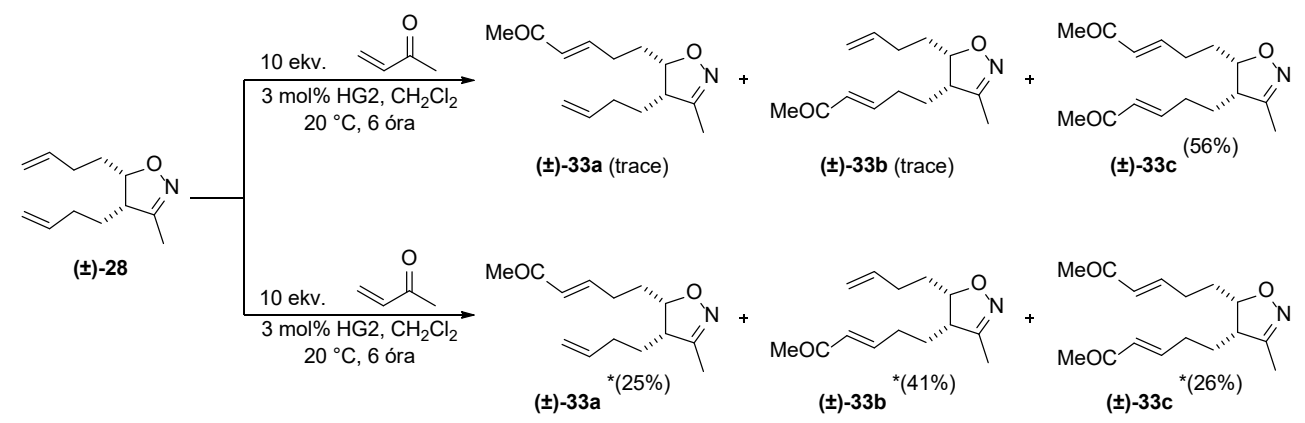

9. ábra. Keresztkapcsolt termékek szintézise metil-vinil-ketonnal (*katalizátor elroncsolással kapott hozamok)

Az egyszeresen kapcsolt regioizomerek $[( \pm)-32 \mathbf{a} / \mathbf{b}$ és $( \pm)-$ 33a/b] oszlopkromatográfiás módszerrel történő elválasztása sikeres volt.

Munkánk során vizsgáltuk a katalizátor jelenlétének hatását is; abban az esetben, ha a katalizátor aktív maradt a reakció feldolgozása során, a metatézis reakció eltolódott a kétszeresen kapcsolt termékek képződésének irányába. Azonban, ha a katalizátort $\mathrm{NaHCO}_{3} / \mathrm{H}_{2} \mathrm{O}, \mathrm{MeOH}$ elegyével elroncsoltuk a reakció feldolgozása során, jelentősebb mennyiségü egyszeresen kapcsolt regioizomerekhez jutottunk. Kísérleti tapasztalataink azt mutatták, hogy az elroncsoláshoz al- kalmazott $\mathrm{NaHCO}_{3} / \mathrm{H}_{2} \mathrm{O}, \mathrm{MeOH}$ elegy nem befolyásolta negatívan a képződött metatézis termékeket. Továbbá a magasabb hőmérséklet szintén kedvez a kétszeresen kapcsolt termékek képződésének.

A keresztmetatézist kiterjesztve divinil-szubsztituált ciklopentánvázzal kondenzált izoxazolinokra ( $( \pm)-29-( \pm)-31$, metil-akriláttal és metil-vinil-ketonnal elvégezve a keresztmetatézis reakciókat hasonló eredményekhez jutottunk. Egyszeresen kapcsolt regioizomerek $( \pm)-34 \mathbf{a b}-( \pm)-39 a b$ és kétszeresen kapcsolt termékek $( \pm)-34 c-( \pm)-39$ c képződtek a reakciók során. (10. ábra)
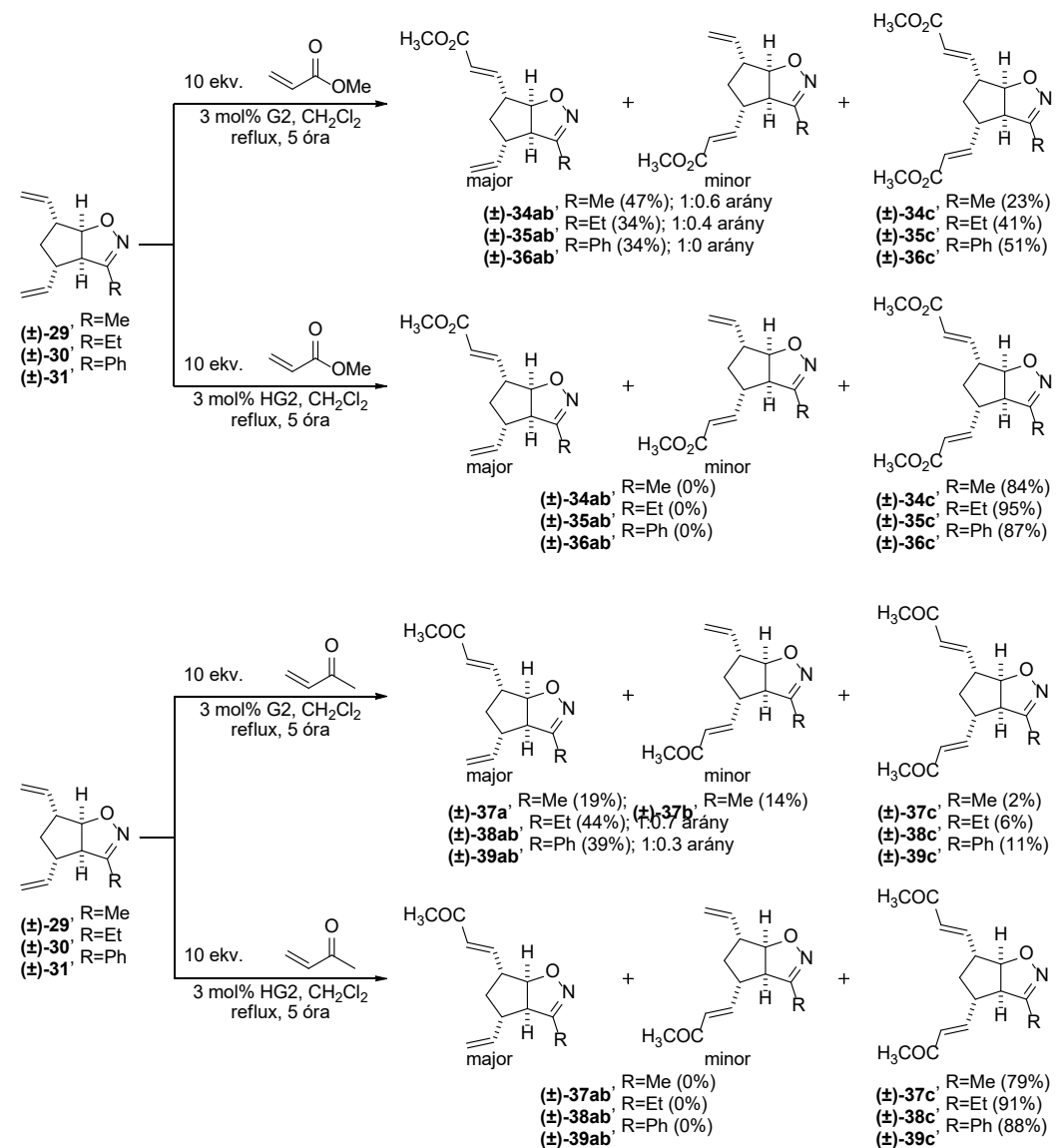

10. ábra. Divinil-ciklopenta-izoxazolin származékok [( \pm -29-( \pm -31] keresztmetatézissel történő átalakítása metil-akriláttal és metil-vinil-ketonnal 
Az egyszeresen kapcsolt regioizomerek [( \pm )-34ab, ( \pm )35ab, $( \pm)$-38ab és $( \pm)-39 a b]$ elválasztása sikertelen volt oszlopkromatográfiás módszerrel, de képződésük arányát minden esetben sikerült meghatározni.

Általánosságban elmondható, hogy a G2 és G3 katalizátorok alkalmazása egyszeresen kapcsolt regioizomereket eredményezett, míg a HG2 katalizátor kétszeresen kapcsolt termékekhez vezetett jó hozammal. A kiindulási anyagként alkalmazott metil-, etil- és fenil-szubsztituált izoxazolin-származékok esetében azt tapasztaltuk, hogy a szubsztituens méretének növekedésével egyenesen arányosan csökken a kisebb mértékben képződött egyszeresen kapcsolt regioizomer $[( \pm)-34 b-( \pm)-39 b]$ aránya. Ez a jelenség sztérikus okokkal volt magyarázható. (11. ábra)

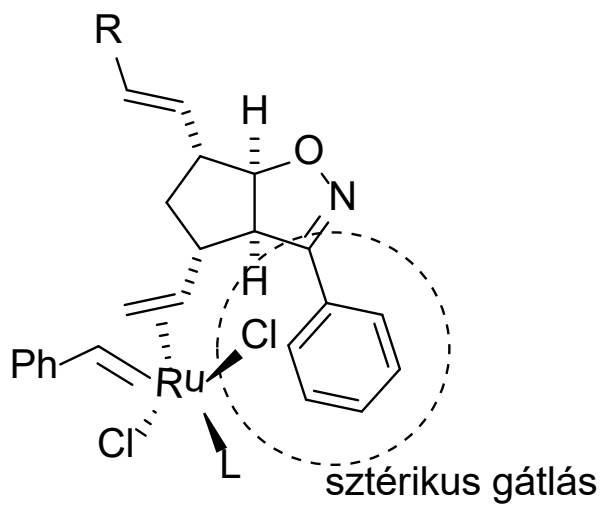

11. ábra. Az átmeneti állapotban kialakuló sztérikus gátlás a katalizátor ligandum és a fenilcsoport között

\subsubsection{Keresztmetatézis fluortartalmú olefinekkel}

A fluortartalmú vegyületek széleskörü biológiai jelentőségét figyelembe véve ${ }^{28-30}$, célunk volt fluortartalmú származékokkal is kiegészíteni az általunk előállított vegyületek körét. Ehhez kapcsoló partnerként fluortartalmú terminális olefineket alkalmaztunk, pl. 2-bróm-3,3,3trifluor-1-propén, 4-bróm-3,3,4,4-tetrafluor-1-butén, allil-1,1,2,3,3,3-hexafluorpropil-éter, metil-2-fluorakrilát, allil-trifluoracetát, 1,1,1,3,3,3-hexafluorizopropil-akrilát, 1H,1H-heptafluorbutil-akrilát, 2,2,2-trifluoretil-akrilát, 4-fluorsztirol, 2-allilhexafluor-izopropanol vagy allil-1H,$1 \mathrm{H}, 2 \mathrm{H}, 2 \mathrm{H}-$ perfluoroktil-éter. A keresztmetatézis reakciókat az előzőekkel megegyező módon $\mathrm{CH}_{2} \mathrm{Cl}_{2}$ közegben $\mathrm{Ru}$ alapú katalizátor (G2, HG2 és G3) jelenlétében végeztük.

Abban az esetben, ha dialkenil-szubsztituált $\beta$-laktámot $[( \pm)$-40 és $( \pm)-44]$ és az $N$-Boc védett párját $[( \pm)-41]$ vagy divinil-szubsztituált biciklusos $\beta$-laktámot $[( \pm)-46]$ és az $N$-Boc védett párját $[( \pm)-47]$ alkalmaztuk kiindulási anyagként a keresztmetatézis reakcióban, kapcsoló partnerként allil-1,1,2,3,3,3-hexafluorpropil-étert, a reakció során egyetlen termék képződött minden esetben, a kétszeresen kapcsolt metatézis termék. Mivel az alkalmazott reagens kiralitáscentrumot tartalmaz, ezért a képződött termékek diasztereomerekként jelentek meg. (12. ábra)

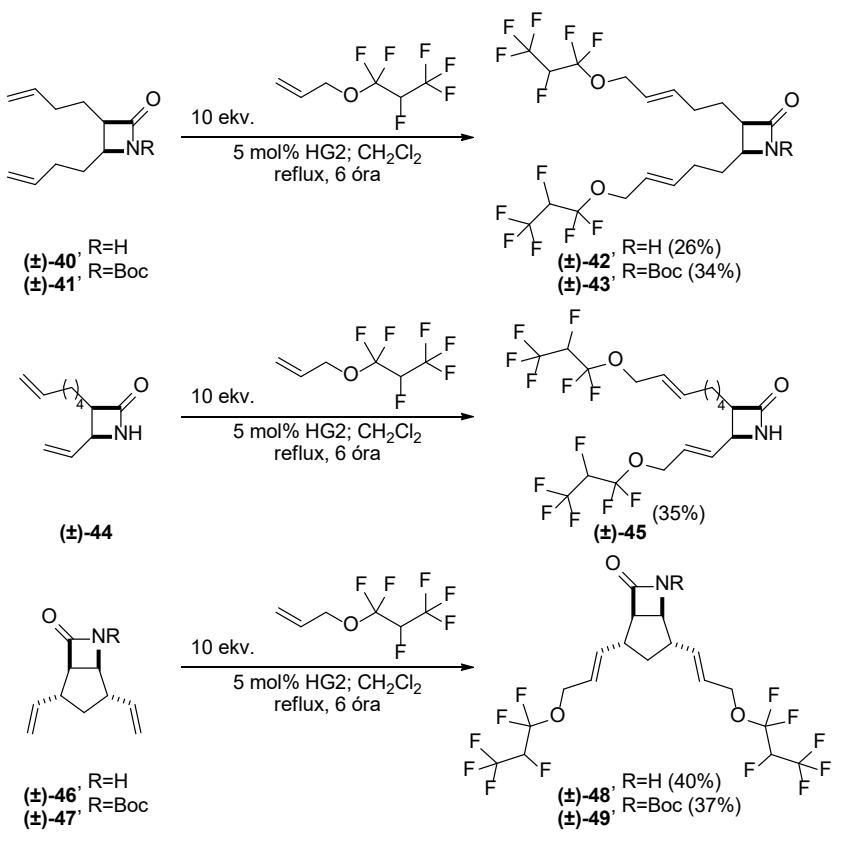

12. ábra. $\beta$-Laktámok keresztmetatézise allil-1,1,2,3,3,3-hexafluorpropil-éterrel

Az $N$-Boc védett $\beta$-laktám $[( \pm)$-50] esetében, ha a reakciót reflux mellett végeztük el a kétszeresen kapcsolt metatézis termék $[( \pm)-51 b]$ mellett egyszeresen kapcsolt metatézisterméket $[( \pm)-51 a]$ is kaptunk. Ez a jelenség két tényezővel volt magyarázható: az egyik a kelátképződés az intermedier és a karbonil-oxigén között, ami gátolja a további reakciót azáltal, hogy stabilizálja az átmeneti állapotot. Másrészről a vinilcsoport sztérikus gátoltsága minimalizálja annak reaktivitását. (13. ábra)

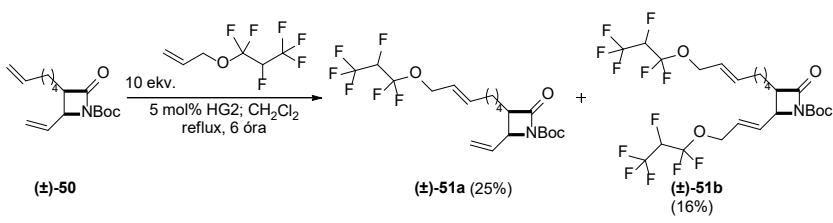

13. ábra. $N$-Boc védett $\beta$-laktám keresztmetatézise allil-1,1,2,3,3,3hexafluorpropil-éterrel

Hőmérsékletfüggő eredményt kaptunk, amikor dialkenil-szubsztituált biciklusos $\beta$-laktámot $[( \pm)-46]$ és $N$-Boc védett [( \pm )-47] analógját alkalmaztuk a keresztmetatézis reakcióban. Szobahőmérsékleten elvégezve a reakciót 1,5:1 arányú egyszeresen kapcsolt regioizomerek $[( \pm)-52 a b$ és ( \pm -53ab] keverékéhez jutottunk. (14. ábra)

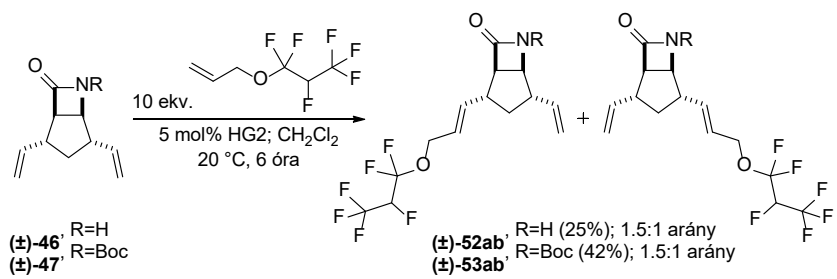

14. ábra. Hőmérsékletfüggő keresztmetatézis termékek 
Di(but-3-én-1-il)-3-metil-izoxazolin $\quad[( \pm)-28]$ kiindulási anyagot, kapcsoló partnerként 4-bróm-3,3,4,4-tetrafluor1-butén, allil-trifluoracetát vagy 2,2,2-trifluoretil-akrilátot alkalmazva a keresztmetatézis reakcióban, egyszeresen kapcsolt regioizomerek $[( \pm)-54 a b,( \pm)-55 a b$ és $( \pm)-56 a b]$ keveréke képződött. (15. ábra)<smiles>C=CCC[C@H]1ON=C(C)[C@@H]1CC/C=C/COC(=O)C(F)(F)C(=O)OCC=C</smiles>

15. ábra. Dialkenil-szubsztituált izoxazolin-származék keresztmetatézise fluortartalmú olefinekkel

A fluortartalmú, szubsztituált izoxazolinok szintézisét kiterjesztettük a divinil-ciklopenta-izoxazolin [( \pm )-29$( \pm)-31]$ származékokra is. Kapcsoló partnerként az alábbi fluortartalmú olefineket használtuk: 1,1,1,3,3,3-hexafluorizopropil-akrilát, $1 \mathrm{H}, 1 \mathrm{H}$-heptafluorbutil-akrilát, 2,2,2-trifluoretil-akrilát, 4-fluorsztirol, 2-allilhexafluorizopropanol vagy allil-1H,1H,2H,2H-perfluoroktil-éter. (16. ábra)<smiles>C=CC(=O)OC(C(F)(F)F)C(F)(F)F</smiles>

1,1,1,3,3,3-hexafluorizopropil-akrilát<smiles>C=CC(=O)OCC(F)(F)F</smiles>

2,2,2-trifluoretil-akrilát<smiles>C=CCC(O)(C(F)(F)F)C(F)(F)F</smiles>

2-allil-hexafluorizopropanol

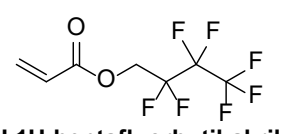

$1 \mathrm{H}, 1 \mathrm{H}$-heptafluorbutil-akrilát

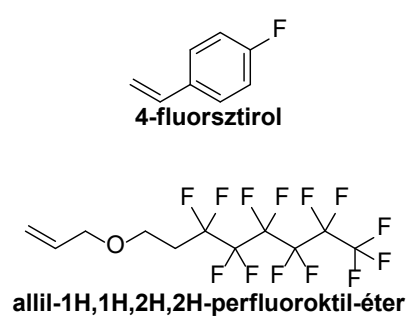

16. ábra. Alkalmazott fluortartalmú olefinek

A keresztmetatézis reakcióban a kereskedelmi forgalomban kapható Ru-alapú katalizátorok közül a G2, HG2 és G3 katalizátorokat alkalmaztuk. Célunk volt az alkalmazott katalizátorok teljesítőképességének és szelektivitásának összehasonlítása is. A reakciók során egyszeresen kapcsolt regioizomerek és kétszeresen kapcsolt termékek is képződtek. (17. ábra)
Általánosságban elmondható, hogy a HG2 katalizátor kétszeresen kapcsolt termékeket $[( \pm)-56 c-( \pm)-71 c]$ eredményezett jelentősebb mennyiségben, ezzel szemben a G2 és a G3 katalizátorok inkább az egyszeresen kapcsolt regioizomerek $[( \pm)-56 a b-( \pm)-71 a b]$ képződésének kedvezett. A regioizomerek elválasztása sikertelen volt. Hasonló tendencia volt megfigyelhető, mint a metil-akrilát és a metil-vinil-keton esetében. Az izoxazolin-gyürün található szubsztituens (metil-, etil-, fenil-szubsztituens) molekulaméretének növekedésével csökkent a kisebb mértékben képződött egyszeresen kapcsolt regioizomer aránya. A fenil-szubsztituált izoxazolin esetében regioszelektivitást értünk el. Ez a jelenség szintén sztérikus okokkal volt magyarázható.

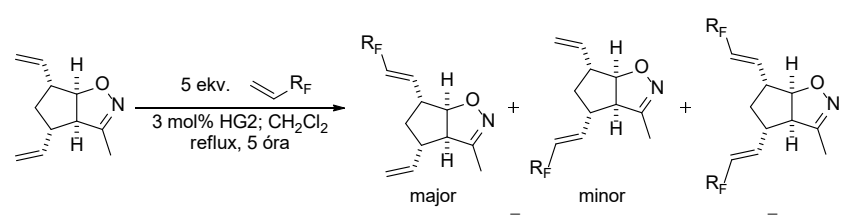

$( \pm)-29$ $( \pm)-56 \mathrm{ab}^{-}( \pm)-61 \mathrm{ab}$

$( \pm)-56 c^{-}( \pm)-61 \mathrm{c}$

\begin{tabular}{|c|c|c|}
\hline $\mathbf{R F}$ & $\begin{array}{c}( \pm)-56 a b-( \pm)- \\
61 a b \text { (arány) }\end{array}$ & $( \pm)-56 c-( \pm)-61 c$ \\
\hline $\mathrm{CO}_{2} \mathrm{CH}\left(\mathrm{CF}_{3}\right)_{2}$ & $10 \%(1: 0.3)$ & $17 \%$ \\
\hline $\mathrm{CO}_{2} \mathrm{CH}_{2}\left(\mathrm{CF}_{2}\right)_{2} \mathrm{CF}_{3}$ & $20 \%(1: 0.3)$ & $34 \%$ \\
\hline $\mathrm{CO}_{2} \mathrm{CH}_{2} \mathrm{CF}_{3}$ & $15 \%(1: 0.3)$ & nyomokban \\
\hline $\mathrm{PhF}$ & $18 \%(1: 0.7)$ & $30 \%$ \\
\hline $\mathrm{CH}_{2} \mathrm{C}\left(\mathrm{CF}_{3}\right)_{2} \mathrm{OH}$ & $15 \%$ & $0 \%$ \\
\hline $\mathrm{CH}_{2} \mathrm{O}\left(\mathrm{CH}_{2}\right)_{2}\left(\mathrm{CF}_{2}\right)_{5} \mathrm{CF}_{3}$ & $6 \%$ & $0 \%$ \\
\hline
\end{tabular}




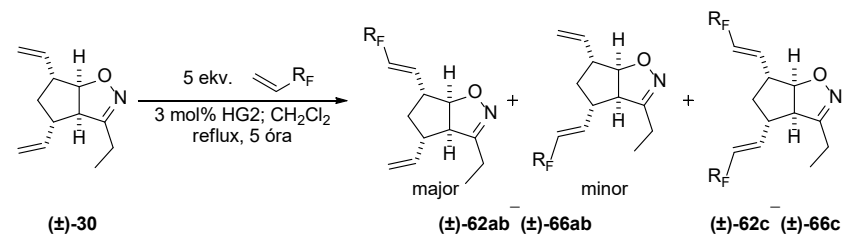

\begin{tabular}{|c|c|c|}
\hline RF & $\begin{array}{c}( \pm)-62 a b-( \pm)-66 a b \\
\text { (arány) }\end{array}$ & $( \pm)-62 c-( \pm)-66 c$ \\
\hline $\mathrm{CO}_{2} \mathrm{CH}\left(\mathrm{CF}_{3}\right)_{2}$ & $2 \%(1: 0)$ & $27 \%$ \\
\hline $\mathrm{CO}_{2} \mathrm{CH}_{2}\left(\mathrm{CF}_{2}\right)_{2} \mathrm{CF}_{3}$ & $9 \%(1: 0.2)$ & $42 \%$ \\
\hline $\mathrm{CO}_{2} \mathrm{CH}_{2} \mathrm{CF}_{3}$ & $7 \%(1: 0)$ & $52 \%$ \\
\hline $\mathrm{PhF}$ & $12 \%(1: 0.5)$ & $38 \%$ \\
\hline $\mathrm{CH}_{2} \mathrm{C}\left(\mathrm{CF}_{3}\right)_{2} \mathrm{OH}$ & $4 \% \quad 21 \%$ & $0 \%$ \\
\hline
\end{tabular}

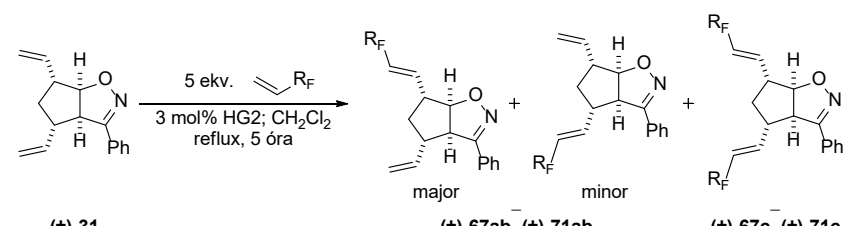

(士)-31

$( \pm)-67 a^{-}( \pm)-71 a b$

$( \pm)-67 c( \pm)-71 c$

\begin{tabular}{lcc}
\hline $\mathbf{R F}$ & $\begin{array}{c}( \pm)-67 a b-( \pm)-71 a b \\
\text { (arány) }\end{array}$ & ( \pm -67c-( \pm -71c \\
\hline $\mathrm{CO}_{2} \mathrm{CH}\left(\mathrm{CF}_{3}\right)_{2}$ & $6 \%(1: 0)$ & $38 \%$ \\
$\mathrm{CO}_{2} \mathrm{CH}_{2}\left(\mathrm{CF}_{2}\right)_{2} \mathrm{CF}_{3}$ & $18 \%(1: 0)$ & $37 \%$ \\
$\mathrm{CO}_{2} \mathrm{CH}_{2} \mathrm{CF}_{3}$ & $4 \%(1: 0)$ & $48 \%$ \\
$\mathrm{PhF}$ & $18 \%(1: 0)$ & $25 \%$ \\
$\mathrm{CH}_{2} \mathrm{C}\left(\mathrm{CF}_{3}\right)_{2} \mathrm{OH}$ & $3 \%(1: 0)$ & $0 \%$ \\
\hline
\end{tabular}

17. ábra. Divinil-3-alkil-ciklopenta-izoxazolinok keresztmetatézise fluortartalmú olefinekkel

\subsection{Heterociklusok előállítása intramolekuláris aza-Michael-addícióval}

A funkcionalizált $N$-heterociklusok számos biológiailag aktív vegyületben (szintetikus heterociklusok és természetes vegyületek) megtalálhatók ${ }^{31-32}$. Az általunk elöállított kétszeresen kapcsolt metatézistermékek, mint potenciális Michael-akceptorok alkalmas szubsztrátokként funkcionálhatnak intramolekuláris aza-Michael-addíciós reakcióban.

Kísérleti munkánk során a $( \pm)-72$ vegyület gyürünyitását végeztük el $23 \% \mathrm{HCl} / \mathrm{EtOH}$ oldatával szobahőmérsékleten, majd ezt követte a bázis katalizálta intramolekuláris aza-Michael-addíció (THF közegben, szobahőmérséklet, DBU bázis, 24 órás reakcióidő). A reakció során, szelektíven, egyetlen terméket kaptunk, a szubsztituált indolizidin vegyületet $[( \pm)-73]$. (18. ábra)

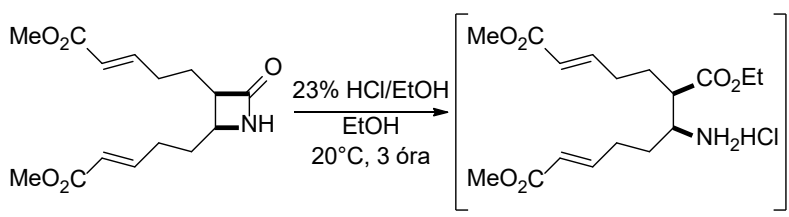

(士)-72

(士)-T73

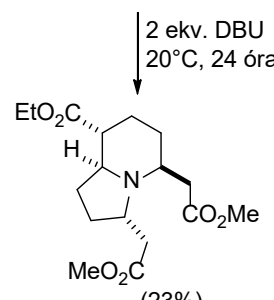

$( \pm)-73^{(23 \%)}$

18. ábra. A ( \pm )-72 vegyület intramolekuláris aza-Michael-addíciója

Abban az esetben, ha az azetidinon gyürünyitását hosszabb reakcióidő alatt (48 óra) végeztük el, az átészterezés is megtörtént. Az így kapott termék [( \pm )-T74] intramolekuláris aza-Michael-addícióját is elvégeztük, az előzőekkel analóg módon kaptuk a megfelelő indolizidin terméket [( \pm )-74]. (19. ábra)

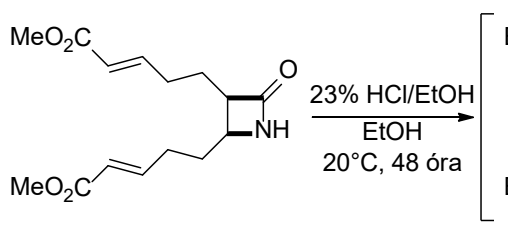

(士)-72<smiles>CCOC(=O)C=CCCC(CCC=CC(=O)OCC)C(N)Cl</smiles>

( $)$-T74

2 ekv. DBU $20^{\circ} \mathrm{C}, 24$ óra

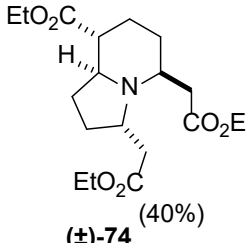

(土) $-74^{(40 \%)}$

19. ábra. A ( \pm -72 vegyület intramolekuláris aza-Michael-addíciója

A Baldwin szabályok ${ }^{33}$ értelmében a gyürüzáródások 5-exo-trig és 6-exo-trig módon történtek, mivel mindkét gyűrüzáródás megengedett, így termékként piperidin/pirrolidin kondenzált (indolizidin) terméket kaptunk. A konjugált addíció során két új sztereogén centrum alakult ki.

Az így előállított indolizidin termékben [( \pm -73 és $( \pm)-74]$ a karboximetil oldalláncok relatív térállása transz, az intramolekuláris aza-Michael addíció diasztereoszelektív módon játszódott le. Az 5S* relatív konfiguráció kialakulása megegyezik azzal a feltevésünkkel, miszerint a hattagú gyűrű szék helyzetű átmeneti állapota és a szubsztituens ekvatoriális helyzete a kedvezményezett a gyürűzáródás során. 


\section{3. Összefoglalás}

Munkánk során izoxazolin-gyűrüvel kondenzált aliciklusokat állítottunk elő 1,3-dipoláros cikloaddícióval. Az 1,3-dipólt Mukaiyama-módszerrel $\left(\mathrm{Boc}_{2} \mathrm{O}, \mathrm{DMAP}\right)$ generáltuk primer nitroalkánból $\left(\mathrm{EtNO}_{2}, n \mathrm{PrNO}_{2}\right.$ és $\left.\mathrm{BnNO}_{2}\right)$ kiindulva. Kiindulási anyagként különböző tagszámú és típusú ciklusos diéneket (ciklopentadién, 1,4-ciklohexadién, 1,3-ciklohexadién, 1,5-ciklooktadién, 1,3-ciklooktadién, illetve 2,5-norbornadién) alkalmaztunk.

Azígy elöállított izoxazolin-származékok sztereokontrollált gyürünyitó metatézisét hajtottuk végre Ru-alapú katalizátorok alkalmazásával, etilén jelenlétében. A melléktermékként képződő polimerek visszaszorítására jó megoldásnak bizonyult a katalizátor elroncsolása $\left(\mathrm{NaHCO}_{3} / \mathrm{H}_{2} \mathrm{O}, \mathrm{MeOH}\right.$ elegy) a reakció feldolgozása során.

A gyürünyitott termékek továbbalakítása kereszt-metatézissel történt. Kapcsoló partnerként $\alpha, \beta$-telítetlen karbonilvegyületeket (metil-akrilát, metil-vinil-keton) használtunk. A reakció során alkalmazott Ru-alapú metatézis katalizátorok teljesítőképességét és szelektivitását is vizsgáltuk. Azt tapasztaltuk, hogy a HG2 katalizátorok jó hozammal eredményezték a kétszeresen kapcsolt termékeket. A keresztkapcsolt termékek minden esetben $E$ geometriával képződtek. Vizsgáltuk, hogy a katalizátor aktivitás milyen hatással van az egyszeresen- és kétszeresen kapcsolt termékek képződési arányára.

A keresztmetatézist elvégeztük fluortartalmú olefinek felhasználásával is. Kapcsoló partnerként 2-bróm-3,3,3trifluor-1-propén, 4-bróm-3,3,4,4-tetrafluor-1-butén, allil-1,1,2,3,3,3-hexafluorpropil-éter, metil-2-fluorakrilát, allil-trifluoracetát, 1,1,1,3,3,3-hexafluorizopropil-akrilát, 1H,1H-heptafluorbutil-akrilát, 2,2,2-trifluoretil-akrilát, 4-fluorsztirol, 2-allilhexafluorizopropanol vagy allil-1H,1H,2H,2H-perfluoroktil-éter vegyületeket alkalmaztuk.

Amikor dialkenil-szubsztituált $\beta$-laktámot és az $N$-Boc védett párját vagy divinil-szubsztituált biciklusos $\beta$-laktámot és az $N$-Boc védett párját alkalmaztuk kiindulási anyagként a keresztmetatézis reakcióban, kapcsoló partnerként allil-1,1,2,3,3,3-hexafluorpropil-étert, a reakció során egyetlen termék képződött minden esetben, a kétszeresen kapcsolt metatézis termék. Azonban az $N$-Boc védett $\beta$-laktám esetében, ha a reakciót reflux mellett végeztük el a kétszeresen kapcsolt metatézis termék mellett egyszeresen kapcsolt metatézisterméket is kaptunk. Hőmérsékletfüggő eredményt kaptunk, amikor dialkenil-szubsztituált biciklusos $\beta$-laktámot és $N$-Boc védett analógját alkalmaztuk a keresztmetatézis reakcióban. A reakciót szobahőmérsékleten elvégezve egyszeresen kapcsolt regioizomerek 1,5:1 arányú keverékéhez jutottunk.

Fluorozott ciklopentán-gyűrủvel kondenzált izoxazolin-származékokhoz jutottunk dialkenil-szubsztituált ciklopenta-izoxazolin vegyületekből kiindulva. Kapcsolópartnerként 1,1,1,3,3,3-hexafluorizopropil-akrilát,
1H,1H-heptafluorbutil-akrilát, 2,2,2-trifluoretil-akrilát, 4-fluor-sztirol, 2-allilhexafluorizopropanol vagy allil-1H,$1 \mathrm{H}, 2 \mathrm{H}, 2 \mathrm{H}$-perfluoroktil-éter vegyületeket használtunk. Minden esetben egyszeresen kapcsolt és kétszeresen kapcsolt termékeket kaptunk. A reakciók során tanulmányoztuk a katalizátorok szelektivitását és azt tapasztaltuk, hogy a HG2 katalizátorok inkább kétszeresen kapcsolt termékek képződését segítette elő, míg a G2 és G3 katalizátorokat alkalmazva egyszeresen kapcsolt termékekhez jutottunk.

Az elóállított keresztkapcsolt termékek alkalmas Michaelakceptoroknak bizonyultak intramolekuláris aza-Michael-addícióban. Az azetidinon gyürủ nyitását $(23 \% \mathrm{HCl} /$ EtOH) követően bázis katalizálta intramolekuláris aza-Michael-addíciót elvégezve egyetlen terméket izoláltunk, a szubsztituált indolizidin vegyületet. Amennyiben az azetidinon gyürủ nyitását hosszabb reakcióidővel végeztük el, abban az esetben az átészterezés is megtörtént. Elvégezve a Michael-addíciót szintén egyetlen termékhez jutottunk az előzőekkel analóg módon.

\section{Köszönetnyilvánítás}

A szerzők köszönetüket fejezik ki az Új Nemzeti Kiválósági Program ÚNKP-18-3-I-SZTE-11, ÚNKP-19-3SZTE-20, ÚNKP-20-3-I-SZTE-309, az NKFIH K 119282, a GINOP-2.3.2-15-2016-00060, az EFOP-3.6.1-16-201600008, a 20391-3/2018/FEKUSTRAT anyagi támogatásáért.

\section{Hivatkozások}

1. Pavlinov, I.; Gerlach, E. M.; Aldrich, L. N. Org. Biomol. Chem., 2019, 17, 1608-1623.

https://doi.org/10.1039/C8OB02327A

2. Hung, A. W.; Ramek, A.; Wang, Y.; Kaya, T.; Wilson, J. A.; Clemons, P. A.; Young, D. W. Proc. Natl. Acad. Sci., 2011, $108,6799-6804$.

https://doi.org/10.1073/pnas.1015271108

3. Collins, S.; Bartlett, S.; Nie, F.; Sore, H.; Spring, D. Synthesis, 2016, 48, 1457-1473. https://doi.org/10.1055/s-0035-1561414

4. Kumar, K. A.; Govindaraju, N. R.; Kumar., G. V. J. Chem. Pharm. Res., 2015, 7, 250-257.

https://www.jocpr.com/articles/isoxazolines-an-insight-totheir-synthesis-and-diverse-applications.pdf

5. Agrawal, N.; Mishra, P. Med. Chem. Res., 2018, 27, 1309-1344.

https://doi.org/10.1007/s00044-018-2152-6

6. Tang, S.; He, J.; Sun, Y.; He, L.; She, X. J. Org. Chem., 2010, 75, 1961-1966.

https://doi.org/10.1021/jo1000065

7. Churykau, D.; Zinovich, V.; Kulinkovich, O. Synlett, 2004, 11, 1949-1952. https://doi.org/10.1055/s-2004-831294

8. Karpavičiene, I.; Lapinskaite, R.; Brukštus, A.; Čikotiene, I. Synlett, 2012, 23, 381-384.

https://doi.org/10.1055/s-0031-1290310

9. Huisgen, R. Angew. Chem., 1963, 2, 565-632. https://doi.org/10.1002/anie.196305651

10. Namboothiri, I. N. N.; Rastogi, N. Synth. Heterocycles Cycloaddit. I (Ed.: A. Hassner), Springer Berlin Heidelberg, 2008, 1-44.

http://link.springer.com/10.1007/7081_2007_101 
11. Kiss, L.; Nonn, M.; Fülöp, F. Synthesis, 2012, 44, 1951-1963. https://doi.org/10.1055/s-0031-1290373

12. Grela, K. Ed. Olefin Metathesis: Theory and Practice, Wiley, Hoboken, New Jersey, 2014. ISBN 978-1118207949 https://doi.org/10.1002/9781118711613

13. Schrodi, Y.; Pederson, R. AldrichimicaActa, 2007, 40, $45-52$.

14. Dias, E. L.; Nguyen, T.; Grubbs, R. H. J. Am. Chem. Soc., 1997, 119, 3887-3897. https://doi.org/10.1021/ja963136z

15. Trnka, T. M.; Grubbs, R. H. Acc. Chem. Res., 2001, 34, $18-29$. https://doi.org/10.1021/ar000114f

16. Chauvin, Y. Angew. Chem. Int. Ed., 2006, 45, 3740-3747. https://doi.org/10.1002/anie.200601234

17. Kiss, L.; Kardos, M.; Vass, Cs.; Fülöp, F. Synthesis, 2018, 50, 3571-3588. https://doi.org/10.1055/s-0036-1591600

18. Benke, Z.; Nonn, M.; Fülöp, F.; Kiss, L. ChemistrySelect 2019, 4, 2886-2891. https://doi.org/10.1002/slct.201900688

19. Tranmer, G. K.; Tam, W. Org. Lett., 2002, 4, 4101-4104. https://doi.org/10.1021/o1026846k

20. Remete, A. M.; Benke, Z.; Kiss, L. Fluorine Notes, 2019, 6 https://doi.org/10.1002/ejoc.201900981

21. Kiss, L.; Benke, Z.; Remete, A. M.; Fülöp, F. Chem. Rec. 2020, 20, 1129-1141. https://doi.org/10.1002/tcr.202000070

22. Benke, Z.; Remete, A. M.; Semghouli, A.; Kiss, L. Asian J. Org. Chem. 2021, 10, 1184-1191. https://doi.org/10.1002/ajoc.202100147

23. Benke, Z.; Nonn, M.; Kardos, M.; Fustero, S.; Kiss, L.; Beilstein J. Org. Chem. 2018, 14, 2698-2707. https://doi.org/10.3762/bjoc.14.247
24. Nonn, M.; Benke, Z.; Fustero, S.; Fülöp, F.; Kiss, L. Eur. J. Org. Chem. 2019, 5285-5293. https://doi.org/10.1002/ejoc.201900101

25. Dinger, M. B.; Mol, J. C. Organometallics, 2003, 22, 1089-1095. https://oi.org/10.1021/om0208218

26. Dinger, M. B.; Mol, J. C. Eur. J. Inorg. Chem., 2003, $2827-2833$. https://doi.org/10.1002/ejic.200200702

27. Jawiczuk, M.; Marczyk, A.; Trzaskowski, B. Catalysts, 2020, 10, 887-943. https://doi.org/10.3390/catal10080887

28. Mei, H.; Remete, A. M.; Zou, Y.; Moriwaki, H.; Fustero, S.; Kiss, L.; Soloshonok, V. A.; Han, J. Chin. Chem. Lett., 2020, 31, 2401-2413. https://doi.org/10.1016/j.cclet.2020.03.050

29. Han, J.; Remete, A. M.; Dobson, L. S.; Kiss, L.; Izawa, K.; Moriwaki, H.; Soloshonok, V. A.; O’Hagan, D. J. Fluor. Chem., 2020, 239, 109639-109666. https://doi.org/10.1016/j.jfluchem.2020.109639

30. Inoue, M.; Sumii, Y.; Shibata, N. ACS Omega, 2020, 5, 10633-10640. https://doi.org/10.1021/acsomega.0c00830

31. Amara, Z.; Caron, J.; Joseph, D. Nat. Prod. Rep., 2013, 30, 1211-1225. https://doi.org/10.1039/c3np20121j

32. Bates, R. W.; Ko, W.; Barát, V. Org. Biomol. Chem., 2020, $18,810-829$. https://doi.org/10.1039/C9OB02388G

33. Baldwin, J. E. J. Chem. Soc. Chem. Commun., 1976, 734-736. https://doi.org/10.1039/c39760000734 


\section{Diversity-oriented synthesis of functionalized alicycles through dipolar cycloaddition/metathesis reaction protocols}

Our resaerch was focused on the preparation of some novel isoxazoline-containing scaffolds starting from varied cyclodienes. Because of their diverse bioactivities, isoxazoline derivatives play an important role in organic and medicinal chemistry. Organic compounds containing the isoxazoline motif are known to have a wide range of biological properties, such as antibacterial, antifungal, anticancer, antiviral, etc. Furthermore, the isoxazoline skeleton is a well-used intermediate in synthetic chemistry. Many valuable compounds are accessed via isoxazoline intermediates, such as amino alcohols, amino diols, and $\beta$-hydroxyketones. Last, but not least, the synthesis of highly functionalized cyclopentane derivatives received considerable attention in medicinal chemistry, due to their various biological activities.

For the formation of the isoxazoline ring, the 1,3-dipolar cycloaddition of nitrile oxide with cycloalkenes is a widely used convenient approach. Since nitrile oxides are reactive and not stable dipoles, they are synthesized in situ. They can be generated utilizing two methods, namely, Huisgen methodology and Mukaiyama methodology. We generated nitrile oxides according to the Mukaiyama method by dehydrating primary nitroalkanes (nitroethane, 1-nitropropane, phenylnitromethane) performed in the presence of a base (DMAP). Various cyclodienes were used as dipolarophiles during the cycloaddition.

Our systematic study started with cyclopentadiene, and besides the cycloaddition adduct, dicyclopentadiene-condensed isoxazoline regioisomers were obtained as main products. Next starting material was 1,4-cyclohexadiene, in this case, only traces of the cycloaddition products were obtained, but starting from its positional isomer the 1,3-cyclohexadiene, regioisomeric products were obtained. The main products in each case were compounds in which the $\mathrm{O}$-atom of the isoxazoline ring located farther from the $\mathrm{sp}^{2} \mathrm{C}$-atom of the cyclohexene ring. When phenylnitromethane was used as the nitrile oxide source, formation of the minor cycloaddition product (when the $\mathrm{O}$-atom of the isoxazoline ring located closer to the $\mathrm{sp}^{2} \mathrm{C}$-atom of the cyclohexene ring) did not occur. In the case of 1,5-cyclooctadiene, a single product was obtained in each case in moderate yield. When 1,3-cyclooctadiene was used as starting material, a mixture of regioisomers was also achieved. In the dipolar cycloaddition reaction of nitrile oxide to 2,5 -norbornadiene, two products were obtained in good yield. The main product was the exo stereoisomer and the by-product was the endo stereoisomer.

Metathesis reaction is an efficient method for $\mathrm{C}=\mathrm{C}$ bond rearrangement. Thanks to its good functional group tolerance, mild reaction conditions, and its capability to create structurally diverse molecules, its use is more and more widespread in synthetic chemistry. Stereocontrolled ring-opening metathesis was accomplished to isoxazoline derivatives, the corresponding ringopened products were obtained with a good to excellent yield. The ring-opening metathesis (ROM) was carried out in ethylene atmosphere, at room temperature in the presence of ruthenium based catalyst $\left(1^{\text {st }}\right.$ generation Grubbs and Hoveyda-Grubbs, $2^{\text {nd }}$ generation Grubbs and Hoveyda-Grubbs, as well as $3^{\text {rd }}$ generation Grubbs catalyst). Small amount of polymeric products were also formed besides ring-opened products. The catalyst degradation proved to be a good solution to repress the polymer formation, for this reason, $\mathrm{NaHCO}_{3} / \mathrm{H}_{2} \mathrm{O}$ and $\mathrm{MeOH}$ solution was used.

ROM of 3-methyl-cyclooctene-isoxazoline was performed, during the reaction, a single product was isolated after purification by column chromatography. In the ROM of isoxazoline derivatives condensed with norbornene skeleton, a single product was isolated. We aimed to test the performance of some commercially available catalysts, we found that the HG1 catalyst resulted in the ring-opened products in good to excellent yields.

For the functionalization of the $\mathrm{C}=\mathrm{C}$ bond, cross metathesis $(\mathrm{CM})$ is a useful and convenient method. The cross metathesis was carried out in $\mathrm{CH}_{2} \mathrm{Cl}_{2}$ in the presence of Ru-based catalysts (G2, HG2, and G3). Methyl acrylate, methyl vinyl ketone, and various fluorinated terminal olefins were used as cross-partners. The reactions took place in a stereocontrolled manner and the products have $E$ geometry in all cases.

During transformation of di(but-3-en-1-yl)-3-methyl-isoxazoline by using methyl acrylate as cross-partner, when the reaction was carried out at room temperature, in the presence of HG2 catalyst for 6 hours significant amount of monocoupled products were formed. When the reaction was executed at reflux, in the presence of HG2 catalyst for 2 hours the dicoupled product was formed in a good yield. In that case, when methyl vinyl ketone was used as cross-partner, the reaction was carried out at room temperature in the presence of HG2 catalyst for 6 hours. During the reaction, monocoupled regioisomers and dicoupled product were obtained and their ratio of formation depends on the reaction conditions. Expanding the cross metathesis to isoxazoline derivatives condensed with divinyl substituted cyclopentane skeleton, CM with methyl acrylate and methyl vinyl ketone gave similar results. During the reactions, monocoupled regioisomers and dicoupled products were formed. Namely, in the case of phenyl substituted derivatives, regioisomer, in which the substituted vinyl moiety was located closer to the substituent of the isoxazoline ring, was not formed. This phenomenon is mostly due to steric reasons.

Considering the wide biological significance of fluorine-containing compounds, we aimed to supplement the range of synthesized compounds with fluorinated derivatives. In that case, when dialkenyl substituted $\beta$-lactam and its $N$-Boc protected counterpart or divinyl substituted bicyclic $\beta$-lactam and its $N$-Boc protected counterpart were used as starting materials in the $\mathrm{CM}$ reaction (in $\mathrm{CH}_{2} \mathrm{Cl}_{2}$, in the presence of $\mathrm{HG} 2$ catalyst, allyl 1,1,2,3,3,3-hexafluoropropyl ether as cross-partner at reflux for $6 \mathrm{~h}$ ) dicoupled products were formed. In the case of $N$-Boc protected $\beta$-lactam when the reaction was carried out at reflux a monocoupled regioisomer also was formed beside the dicoupled product. Two factors may contribute to the outcome of the reaction: the chelation of the metallacycle intermediate with the carbonyl oxygen and the steric hindrance. The results were found to be temperature dependent, when dialkenyl substituted bicyclic $\beta$-lactam and its $N$-Boc protected counterpart were used as starting material. When the reaction was executed at room temperature mixture of monocoupled regioisomers was obtained in a ratio of 1.5:1. When di(but-3-en1-yl)-3-methylisoxazoline as starting material, 4-bromo-3,3,4,4tetrafluoro-1-butene, allyl trifluoroacetate or 2,2,2-trifluoroethyl acrylate as cross-partners were used in the $\mathrm{CM}$ reaction, a mixture of monocoupled regioisomers was formed. The synthesis of fluorine containing divinyl-cyclopenta-isoxazoline derivatives was expanded. During the reactions, monocoupled regioisomers and dicoupled products were formed. Regioselectivity was achieved in the case of phenyl-substituted isoxazoline as well.

The synthesized dicoupled cross metathesis products function as Michael acceptor substrates in intramolecular aza-Michael additions. Lactam ring-opening was executed, followed by base catalyzed intramolecular aza-Michael addition, a single product was obtained, a substituted indolizidine compound. When the 2-azetidinon ring-opening with $\mathrm{HCl} / \mathrm{EtOH}$ solution was performed for a longer reaction time $(48 \mathrm{~h})$, in addition to the ring-opening, transesterification also took place. The intramolecular aza-Michael addition of the resulting product was also executed. 